\title{
Pengembangan Bahan Ajar Pembelajaran Matematika Realistik Indonesia pada Materi Bangun Datar
}

\author{
Ganung Suko Saputro ${ }^{1}$, Hikmatul Khusna ${ }^{2}$ \\ 1,2 Prodi Pendidikan Matematika, Fakultas Ilmu Pendidikan dan Keguruan, Universitas Muhammadiyah Prof. Dr. Hamka, \\ Jl. Tanah Merdeka, Rambutan, Jakarta Timur, DKI Jakarta, Indonesia \\ hikmatulhusna@uhamka.ac.id
}

\begin{abstract}
This research is motivated because mathematics is abstract in the explanation of concepts and the lack of availability of teaching materials about PMRI. The researcher develops Indonesian realistic mathematics learning book products in flat shapes. The method used by ADDIE is analysis, design, develop, implementation, and evaluation. Validation was obtained through validation experts including materials, media, and mathematics teachers. The results of the material expert validation study obtained a calculation of $93.6 \%$ in the valid category without revision and the media expert validation obtained a calculation of $79 \%$ in the valid category with revision. An assessment was also obtained from the mathematics teacher by giving the calculation $96.66 \%$ valid without revision. The conclusion is that the Indonesian realistic mathematics learning book product in flat shapes is valid and feasible to use.
\end{abstract}

Keywords: ADDIE, RME, Bangun Datar

\begin{abstract}
Abstrak
Penelitian ini dilatarbelakangi karena matematika bersifat abstrak pada penjelasan konsep dan kurang tersedianya bahar ajar tentang PMRI. Peneliti melakukan pengembangan produk buku pembelajaran matematika realistik Indonesia pada bangun datar. Metode yang digunakan ADDIE adalah analysis, design, develop, implementation, dan evaluation. Validasi diperoleh melalui ahli validasi antara lain materi, media, dan guru matematika. Hasil dari penelitian validasi ahli materi memperoleh perhitungan 93,6\% berkategori valid tanpa revisi dan validasi ahli media memperoleh perhitungan $79 \%$ berkategori valid dengan revisi. Penilaian juga diperoleh dari guru matematika dengan memberi perhitungan $96,66 \%$ valid tanpa revisi. Kesimpulannya adalah produk buku pembelajaran matematika realistik Indonesia pada bangun datar valid dan layak digunakan.
\end{abstract}

Kata kunci: ADDIE, PMRI, Bangun Datar

Copyright (c) 2021 Ganung Suko Saputro, Hikmatul Khusna

$\triangle$ Corresponding author: Hikmatul Khusna

Email Address: hikmatulhusna@uhamka.ac.id (J1 Tanah Merdeka, Rambutan, Pasar Rebo, Jakarta Timur)

Received 14 July 2021, Accepted 22 July 2021, Published 08 August 2021

\section{PENDAHULUAN}

Matematika mendapatkan peran penting dalam menentukkan kehidupan nyata. Beberapa peserta didik masih menyatakan bahwa mata pelajaran matematika adalah yang tersulit. Hal tersebut disetujui oleh (Sholihah \& Afriansyah, 2018) matematika mempunyai peranan krusial pada kehidupan, pada praktik pembelajarannya sebagian peserta didik masih menduga matematika menjadi mata pelajaran yang sulit. Matematika dikatakan sulit dikarenakan sifatnya abstrak sehingga siswa mengalami kesulitan menyelesaikan masalah. Siswa mengalami kesulitan menyelesaikan masalah pada aspek konsep matematika. Menurut (Maryamah et al., 2019) salah satu aspek kunci yang mendasari penyelesaian masalah adalah keuletan siswa untuk memahami konteks masalah, terutama konsep matematika. Pemahaman konsep matematika menjadi dasar utama dalam menyelesaikan pemecahan masalah matematika.

Karena merupakan ilmu mendasar yang diterapkan secara luas di semua bidang kehidupan, matematika memainkan peran yang sangat penting (Masfingatin, 2014). Pembelajaran matematika yakni pola berpikir yang logis dan jelas sehingga membutuhkan konsep yang terperinci untuk menyelesaikan 
persoalan pada kejadian yang nyata (Pangestu et al., 2019). Untuk memecahkan permasalahan matematika yang bersifat abstrak dapat diselesaikan dengan menggunakan kehidupan sehari-hari. Menurut (Afriansyah, 2016) pandangan pertama bahwa matematika itu wajib dekat dengan peserta didik dan terkait dengan situasi kehidupan sehar-hari peserta didik. Matematika akan menjadi lebih mudah karena siswa sering menghadapi situasi yang mereka kenal.

Menurut (Rofiroh, 2019) sifat abstrak matematika bisa diatasi menggunakan penerapan pendekatan realistik dalam bahan ajar matematika. Menjelaskan sifat keabstrakan itu salah satunya dapat dideskripsikan dengan cara melihat langsung secara konkret, ini sesuai dengan hakikat dari realistik tersebut yang mana mengharuskan siswa ikut serta aktif dalam melihat objek yang dituju. Hal ini sudah dibuktikan melalui jurnal berjudul "Pengembangan Bahan Ajar Matematika dengan Pendekatan Pendidikan Matematika Realistik Indonesia pada Materi Sistem Persamaan Linier Dua Variabel” oleh (Mahmudah \& Fathani, 2019) menyatakan bahwa matematika realistik pada bahan ajar dapat membantu menjelaskan kepada peserta didik sesuatu abstrak menjadi konkret. Pembelajaran matematika realistik muncul dilatarbelakangi oleh pendapat Hans Freudenthal bahwasannya matematika merupakan aktivitas manusia, dan dirasa sangat cocok untuk diadopsi dan diterapkan di Indonesia, sehingga diberi nama pendekatan matematika realistik Indonesia atau disingkat PMRI (Ulya et al., 2019). Menurut (Marlinda \& Wijaya, 2018) pembelajaran yang mengutamakan inovasi kembali, pengertian konsep melalui permasalahan kontekstual, dan hal yang konkrit yakni pembelajaran yang mengadaptasi PMR, sehingga lingkungan peserta didik menggunakan proses matematisasi oleh peserta didik mengkonstuksikan idenya sendiri. Pembelajaran berorientasi PMR mengenalkan konsep melalui pertanyaan kontekstual, objek konkret, atau merumuskan ide di lingkungan siswa, mengenalkan konsep melalui proses komputasi siswa, dan mengutamakan ekspresi. Pembelajaran matematika realistik selayaknya dimulai dari sesuatu yang nyata atau kegiatan yang dekat dengan peserta didik (Ahmad \& Nasution, 2018). PMRI menjadi dobrakan baru untuk meningkatkan prestasi siswa pada pembelajaran matematika.

(Marlinda \& Wijaya, 2018) menyebut Nugra-heni \& Sugiman (2013) menyatakan untuk perbaikan kualitas pendidikan matematika pada Indonesia adalah dengan pendekatan matematika realistik. Pendekatan Realistic Mathematics Education (RME) mengutamakan tata cara peserta didik menemukan kembali konsep dalam matematika dalam permasalahan yang nyata bagi peserta didik (Ja'far et al., 2014). Matematika dengan mudah dipahami oleh siswa dikarenakan permasalahan langsung mereka hadapi dan mereka dapat berkreasi menyelesaikannya. Disampaikan juga bahwa matematika merupakan respon kegiatan manusia artinya peserta didik berupaya menemukan kembali konsep matematika dengan mandiri (Ja'far et al., 2014).

Materi bangun datar yakni materi yang penting dalam pembelajaran matematika. Salah satu materinya yaitu tentang sifat, luas, dan kelilung pada persegi, persegi panjang, segitiga, trapesium, jajargenjang, belah ketupat, layang-layang (Sandri, 2018). Tidak sedikit peserta didik mengalami kesulitan belajar matematika pada materi bangun datar seperti yang diungkapkan oleh (Lisnani \& Asmaruddin, 2018) bangun datar membutuhkan pendalaman konsep yang mendalam untuk peserta didik karena cenderung 
abstrak pada soal-soal pemecahan masalah. Penjelasan tersebut jelas bahwa kesulitan yang banyak dialami siswa karena matematika pada materi bangun datar bersifat abstrak. Dijelaskan juga oleh (Mayani \& Rizki, 2016) salah satu tantangan yang didapati peserta didik dalam menyelami ilmu matematika adalah cangkupan materi matematika yang jauh dari aktivitas yang sebenarnya. Maka perlu adanya pembelajaran yang dapat memfasilitasi hal tersebut. PMRI merupakan pembelajaran yang mengarahkan permasalahan matematika dengan kehidupan nyata. Menurut (Fitria Herliani \& Wardono, 2019) pendekatan pembelajaran matematika realistik menumpu dalam matematisasi pengalaman konkret keseharian peserta didik dan bisa dikaitkan menggunakan lingkungan sekitar sehingga metematika menjadi kegiatan peserta didik. PMRI membuat siswa dapat memahami dengan mudah materi bangun datar karena sesuai dengan pengalaman mereka pada kehidupan sehari-hari.

Untuk mewujudkan hal tersebut diharuskan bahan ajar yang mampu mengakomodasi pembelajaran PMRI pada materi bangun datar. Menurut (Mahmudah \& Fathani, 2019) dengan pendekatan PMRI adalah solusi yang ditawarkan peserta didik pada membentuk pembelajaran yang efektif dan efisien sehingga tercapai tujuan yang diinginkan. Bahan ajar yang tersedia di sekolah belum sepenuhnya melibatkan kehidupan sehari-hari karena guru masih berpatokan pada buku yang disediakan sekolah. Dengan demikian perlu adanya bahan ajar yang mengakomodasi PMRI. Menurut (Mayani \& Rizki, 2016) solusi dalam menyelesaikan permasalahan konkrit adalah dengan menggunakan pembelajaran yang berbasis realistik. Berdasarkan latar belakang, materi bangun datar pada pelajaran matematika masih bersifat abstrak. Maka penelitian ini difokuskan pada model bahan ajar buku tentang pembelajaran matematika realistik Indonesia guna lebih memahami materi bangun datar pada peserta didik.

\section{METODE}

Penelitian ini disusun pada metode pengembangan Research dan Development (R\&D). Menurut Gay, penelitian pengembangan merupakan menciptakan suatu produk untuk menjadi yang lebih efisiensi digunakan pada peserta didik (Baiq Hana Susanti, Fransisca, 2016). Pada penelitian ini peneliti menggunakan model ADDIE. ADDIE merupakan tahapan yang terdiri dari Analysis, Design, Develop, Implementation, dan Evaluation.

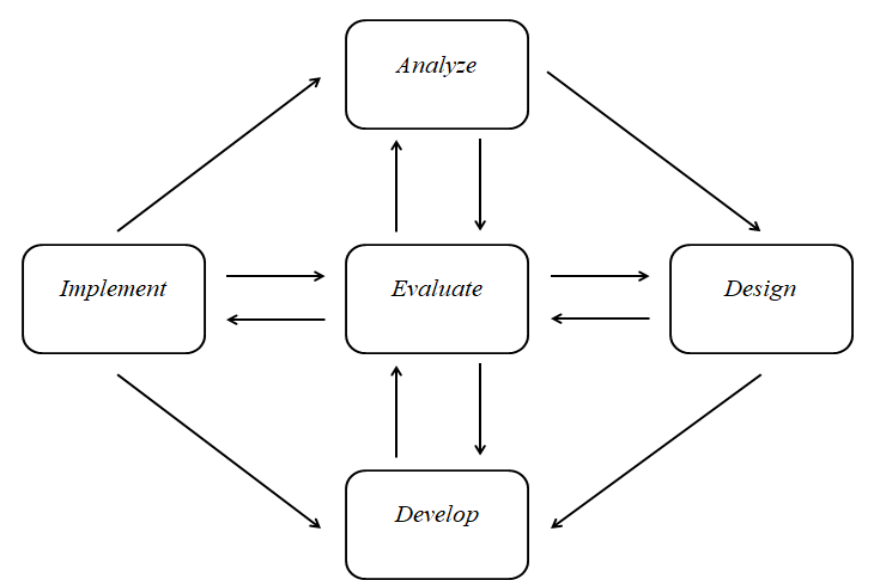

Gambar 1. Peta Pengembangan Model ADDIE 
Bahan ajar yang telah dirancang akan dinilai oleh validasi ahli. Pada tahap validasi ahli ini dilakukan 3 validasi yaitu media, materi, dan guru matematika untuk memvalidasi bahan ajar yang dikembangkan. Validasi ahli dan guru dimasukkan ke dalam analisis menggunakan skala likert.

Tabel 1. Skala Likert (Ihsan, 2019).

\begin{tabular}{|c|c|}
\hline Skor (\%) & Pilihan Jawaban \\
\hline $81,0 \%-100,0 \%$ & Sangat valid, digunakan tanpa revisi \\
\hline $61,0 \%-80,0 \%$ & Cukup valid, digunakan perlu revisi \\
\hline $41,0 \%-60,0 \%$ & Netral, digunakan perlu revisi \\
\hline $21,0 \%-40,0 \%$ & Kurang valid, perlu revisi \\
\hline $0,0 \%-20,0 \%$ & Tidak valid, tidak digunakan \\
\hline
\end{tabular}

Pada tahap implementasi bahan ajar ini, peneliti melakukan penyebaran pada bahan ajar yangs sudah di validasi oleh ahli. Penyebaran ini bersifat terbatas yaitu kepada guru matematika yang mengajar di sekolah. Setelah melakukan implementasi, masuk ke dalam tahap evaluasi yaitu menganalisis hasil validasi ahli dan juga penilaian dari guru matematika apakah produk bahan ajar yang dibuat peneliti di terima oleh peserta didik secara umum atau tidak.

\section{HASIL DAN DISKUSI}

Berdasarkan penelitian tersebut pengembangan produk buku pembelajaran matematika realistik Indonesia pada bangun datar yang telah dilakukan, diperoleh hasil dengan model penelitian ADDIE.

\section{Analisis}

Pada tahap analisis, peneliti menganalisis permasalahan pada materi bangun datar pada kelas VII dengan menganalisis berbagai buku dengan materi bangun datar. Peneliti menganalisis bahwa bahan ajar materi bangun datar masih terkesan abstrak pada penjelasan konsep. Sehingga peneliti mengadopsi materi bangun datar kepada pembelajaran matematika realistik Indonesia sebagai salah satu solusi penyelesaian. Dengan mengadopsi pembelajaran matematika realistik Indonesai pada bangun datar, peserta didik akan dibawa eksperimen dengan penemuan kembali, lalu menemukan fenomena didaktik, dan peserta didik menemukan model penyelesaian yang dbangun sendiri.

\section{Desain}

Tahap desain, peneliti membuat bahan ajar ini sesuai tahap analisis. Peneliti melakukan penyusunan peta konsep kebutuhan bahan ajar dan melakukan penilain kevalidan kepada para ahli. Dalam penyusunan bahan ajar ini peneliti memperhatikan silabus tentang bangun datar yaitu segiempat dan segitiga. Selanjutnya, peneliti melakukan kolaborasi antara bangun datar dengan matematika realistik Indonesia. hal ini untuk memudahkan peneliti untuk menyajikan buku sesuai dengan relevansi peserta didik. Pada bahan ajar ini menyajikan tentang keliling dan luas bangun datar melalui pembuktian realistik. Peneliti juga mengacu pada struktur bahan ajar. Hasil rancangan buku pembelajaran matematika realistik Indonesia pada bangun datar diperlihatkan pada gambar sebagai berikut. 
Pengembangan Bahan Ajar Pembelajaran Matematika Realistik Indonesia pada Materi Bangun Datar, Ganung Suko Saputro,

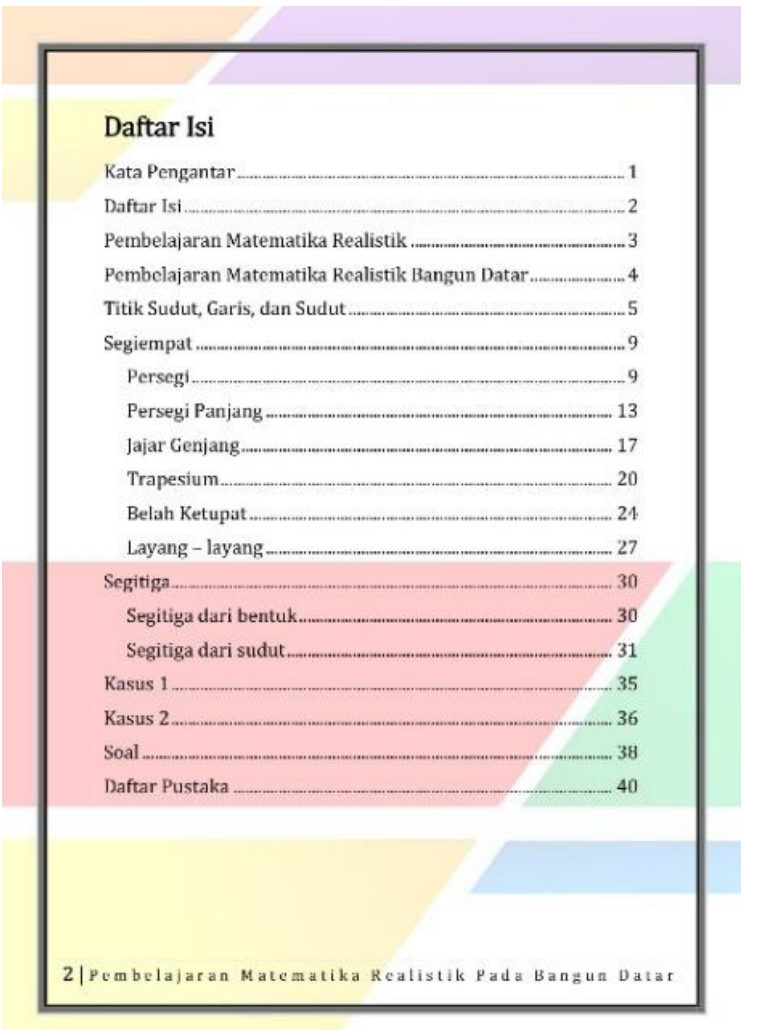

Gambar 4. Daftar Isi

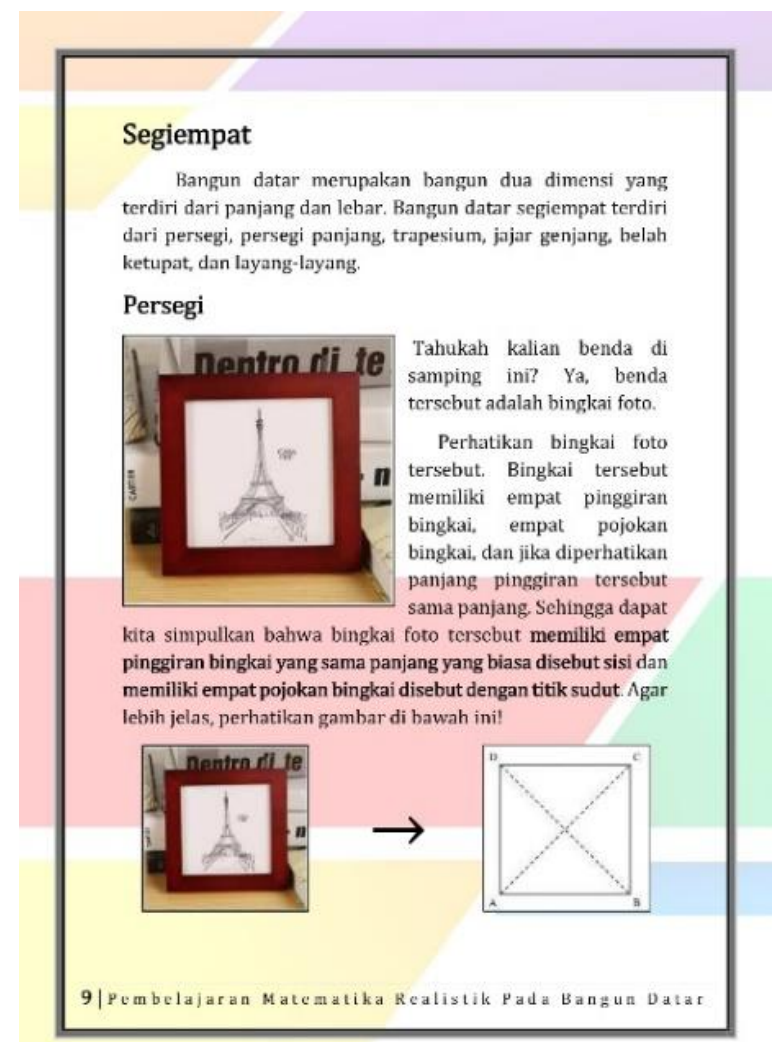

Gambar 6. Isi Materi

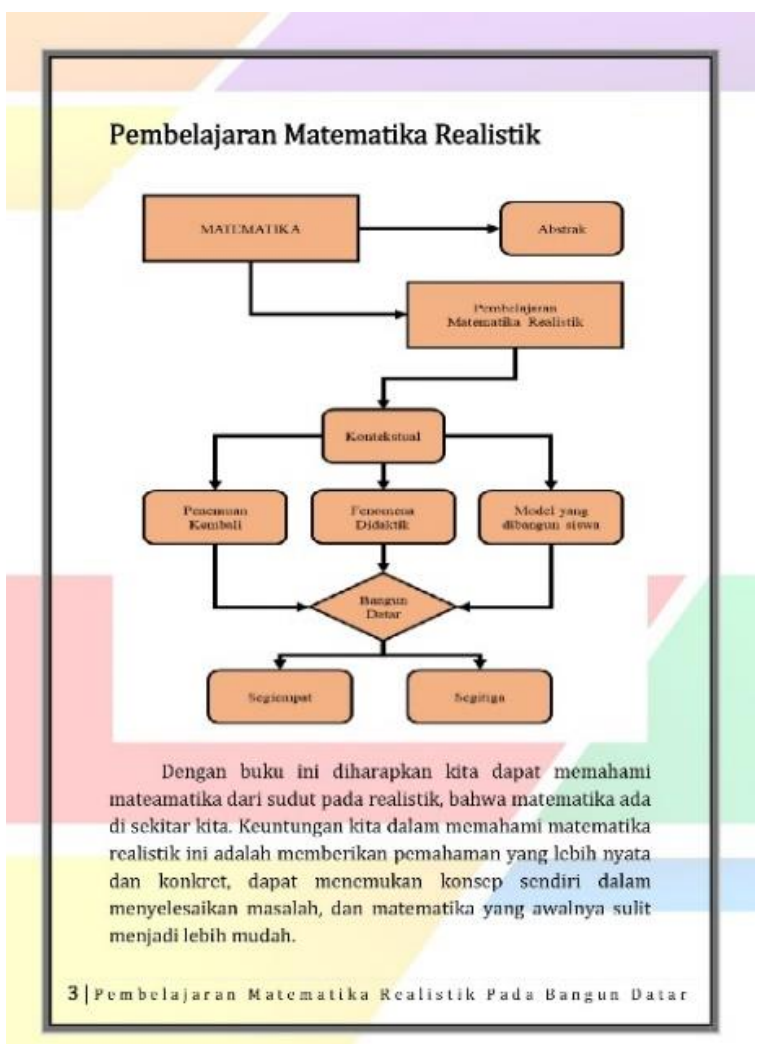

Gambar 5. Peta Konsep

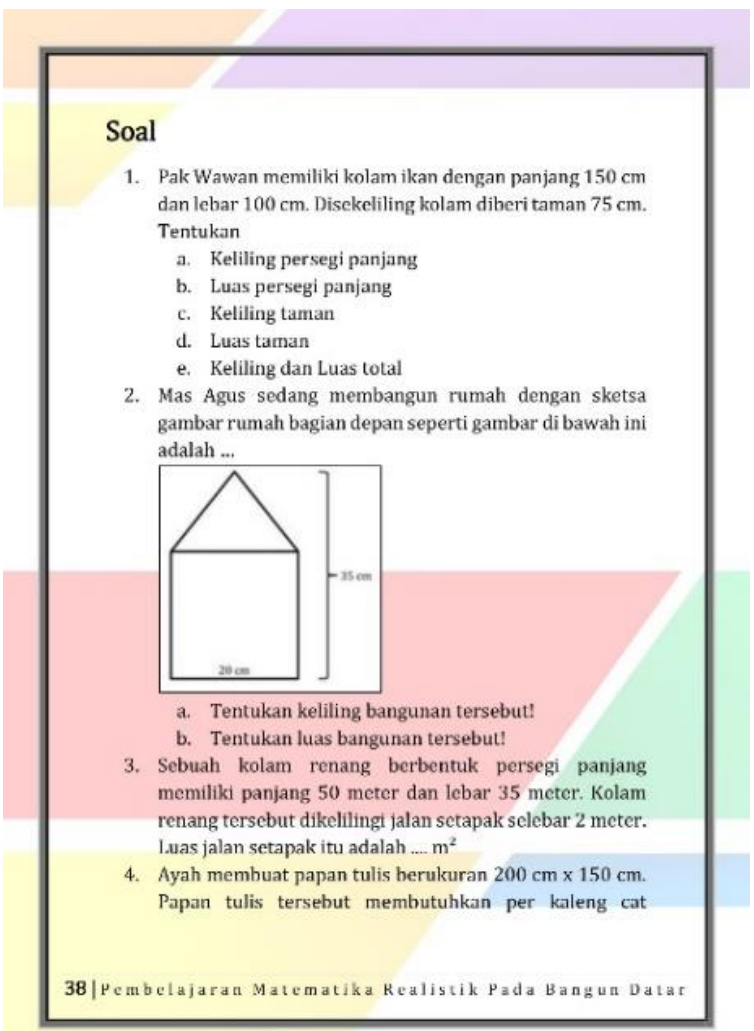

Gambar 7. Soal 


\section{Pengembangan}

Tahap pengembangan, Bahan ajar akan dilakukan uji kevalidan pada produk buku yang sudah dirancang. Produk buku yang telah dirancangkan akan dinilai oleh penilaian ahli. Penilaian validasi pada buku ini terbagi menjadi dua validasi yaitu materi dan media. Penilaian pada validasi ahli materi mengenai aspek kesesuaian materi, petunjuk belajar, dan evaluasi pada bahan ajar. Sedangkan penilaian pada validasi ahli media mengenai aspek tampilan, petunjuk, warna, dan kejelasan bentuk yang sesuai materi bahan ajar. Hasil penilaian dari ahli materi tentang produk buku pembelajaran matematika realistik pada materi bangun datar menyatakan sangat valid dengan presentase 93,6\%. Sedangkan, hasil penilaian dari ahli media pada bahan ajar menyatakan cukup valid dengan presentase $79 \%$. Walaupun bahan ajar memilki tingkat validasi yang cukup valid, terdapat beberapa catatan menurut ahli materi dan menurut ahli media. Ahli materi memberi saran untuk memunculkan 5 karakteristik PMRI dalam aktivitas belajar dan perlu konsisten dalam menyediakan ruang siswa dalam menjawab pertanyaan dalam bahan ajar. Sedangkan ahli media memberi saran tentang cover terlihat sangan kaku, kurang menarik dan tidak ada gambar bangun datar realistik dan warna gradasi pada bahan ajar kurang menarik.

\section{Implementasi}

Tahap implementasi, penerapan buku tentang Pembelajaran Matematika Realistik Indonesia pada bangun datar dilakukan dengan cara penelitian terbatas yaitu di uji dengan respon guru matematika. Berdasarkan hal tersebut, respon guru terhadap produk buku Pembelajaran Matematika Realistik Indonesia pada bangun datar mencapai presentase 96,66\% dan masuk dalam kategori sangat valid bahwa produk buku ini tidak perlu adanya perubahan dan dapat digunakan oleh peserta didik. Walaupun memberikan penilaian validasi sangat valid, guru matematika juga memberikan saran terhadap bahan ajar yaitu tulisan judul dan cover yang terlalu monoton dan kaku.

\section{Evaluasi}

Terakhir tahap evaluasi, berdasarkan seluruh penilaian validasi oleh kedua ahli dan respon guru matematika terhadap buku pembelajaran matematika realistik Indonesia pada bangun datar rata-rata mendapatkan tingkat validasi yang cukup valid, walaupun masih ada revisi untuk menyempurnakan bahan ajar. Peneliti melakukan perbaikan terhadap cover bahan ajar yang menjadi sorotan terlihat kaku dan monoton. 

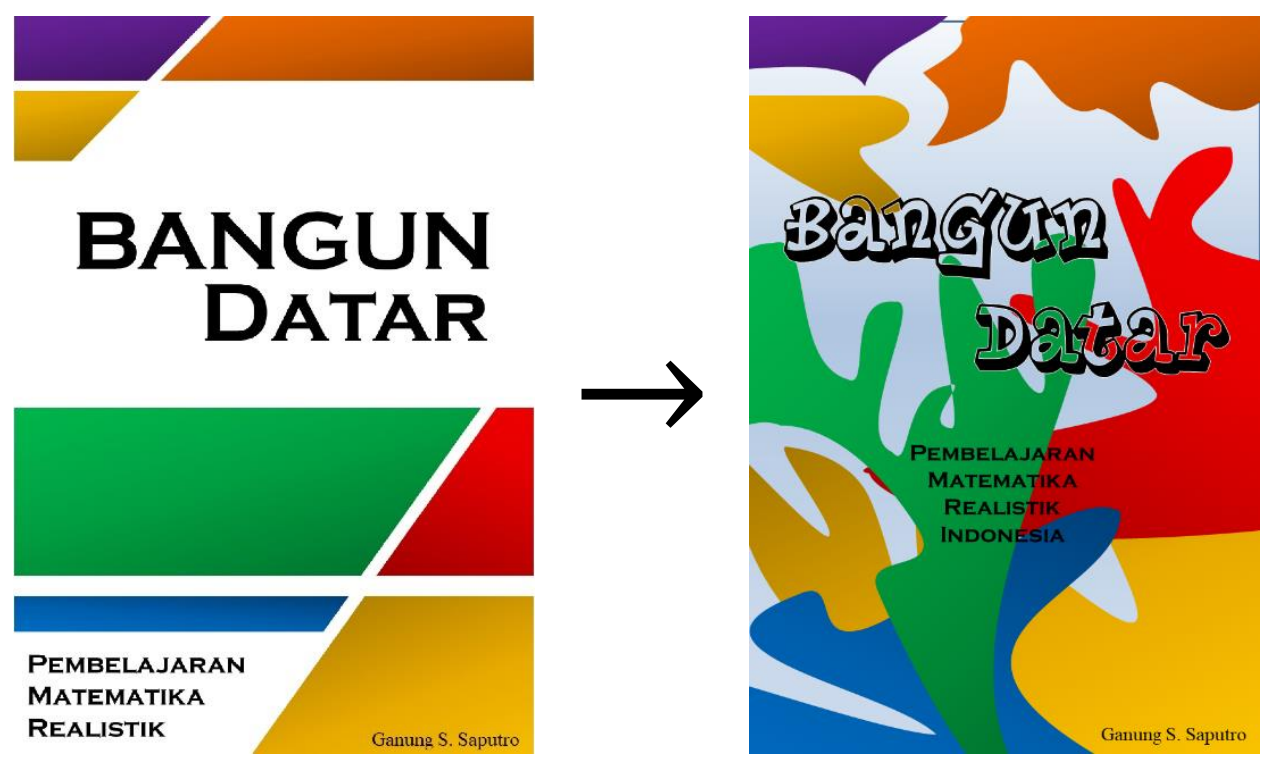

Sebelum

Sesudah

Gambar 8. Revisi cover bahan ajar
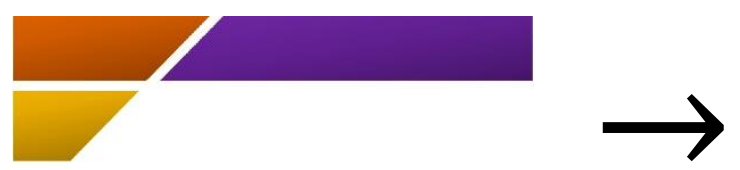

Bangun Datar merupakan bangun dua dimensi yang terdiri dari panjang dan lebar: Bangun datar memiliki macam-macam bangunan antara lain yaitu persegi, persegi panjang, segitiga, trapesium, jajar genjang, belah ketupat, layang-layang, dan lingkaran.
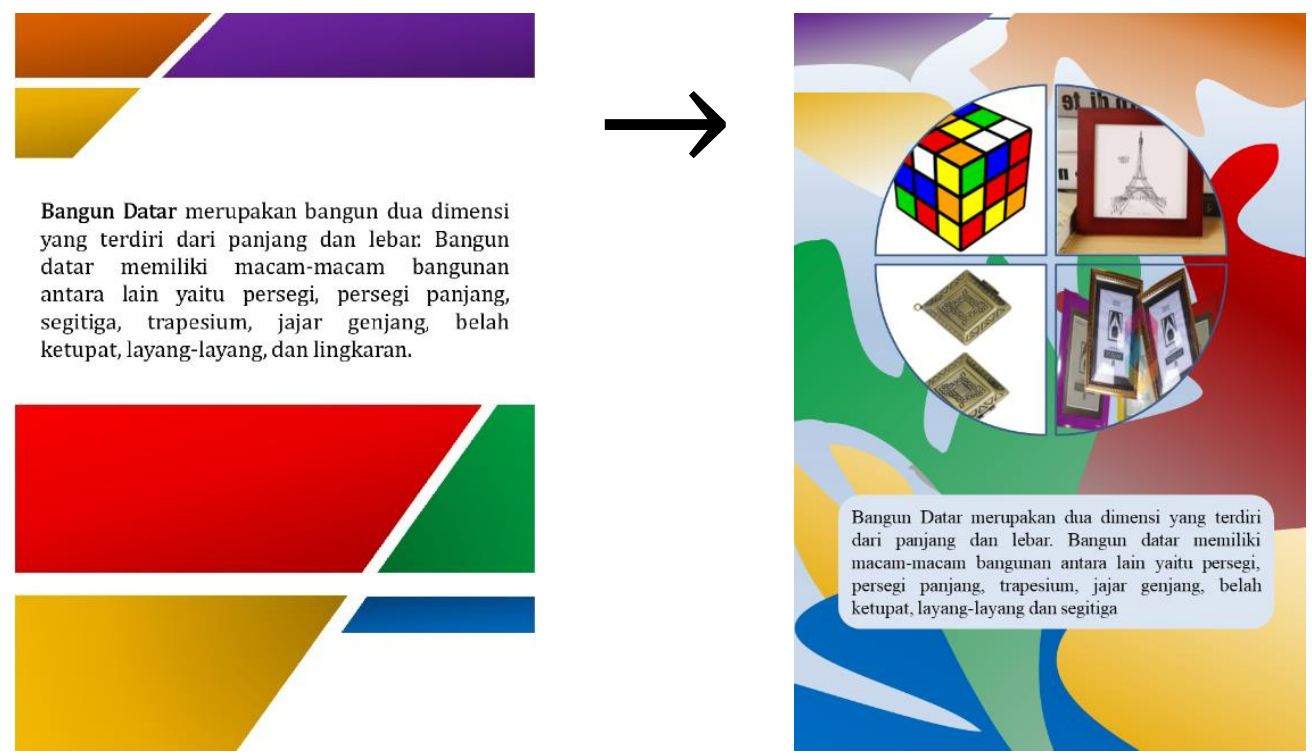

Gambar 9. Revisi bahan ajar

Produk buku pembelajaran matematika realistik Indonesia pada materi bangun datar ini diharapkan menjadi pedoman belajar para peserta didik. Pada bahan ajar buku ini peserta didik diajak menemukan konsep bangun datar dengan pembelajaran matematika realistik, menemukan keliling dan luas bangun datar dengan pembelajaran matematika realistik, sehingga peserta didik lebih memahami konteks pada bangun datar secaraa konkret.

\section{KESIMPULAN}

Produk buku Pembelajaran Matematika Realistik Indonesia pada bangun datar telah memenuhi kevalidan dengan beberapa yang harus diperbaiki. Bahan ajar memenuhi aspek kevalidan dari ahli materi dan ahli media yang menyatakan bahwa produk tersebut layak digunakan. Penilaian materi memberikan 
penilaian dengan presentase $93,6 \%$ dan penilaian media menyampaikan penilaian dengan presentase $79 \%$. Penilaian selanjutnya dengan guru matematika dengan memberikan penilaian validitas $96,66 \%$ sehingga buku pembelajaran matematika realistik Indonesia pada bangun datar layak digunakan ke peserta didik. Berlandaskan hasil pembahasan penelitian dan analisis yang telah dipenuhi, dapat disimpulkan bahwa bahan ajar Pembelajaran Matematika Realistik Indonesia Pada Bangun Datar dikategorikan valid dan dapat dimanfaatkan sebagai referensi guru dalam mengajar tentang Pembelajaran Matematika Realistik Indonesia.

\section{UCAPAN TERIMA KASIH}

Kami mengucapkan puja dan puji syukur kepada Allah SWT yang telah memberikan kesehatan dan kemajuan dalam penyelesaian artikel ini. Kami juga mengucapkan Shalawat kepada Nabi Muhammad SAW sebagai rasa syukur dan semangat. Selanjutnya, kami mengucapkan rasa terima kasih banyak kepada orang tua yang telah memberikan kebulatan hati sehingga dapat menyelesaikan artikel ini. Dan terakhir saya mengucapkan rasa banyak terima kasih kepada dosen pembimbing Ibu Hikmatul Khusna yang telah memberikan ilmu dan waktunya.

\section{REFERENSI}

Afriansyah, E. A. (2016). Makna Realistic dalam RME dan PMRI. Lemma, II(2), 96-104.

Ahmad, M., \& Nasution, D. P. (2018). Analisis Kualitatif Kemampuan Komunikasi Matematis Siswa Yang Diberi Pembelajaran Matematika Realistik. Jurnal Gantang, 3(2), 83-95. https://doi.org/10.31629/jg.v3i2.471

Baiq Hana Susanti, Fransisca, S. S. R. (2016). Pengembangan Dan Implementasi Program Perkuliahan Vertebrata Berbasis Learning Object Dengan Sistem E- Learning Di Program Studi Pendidikan Biologi Fitk Uin Jakarta. 554-563.

Fitria Herliani, E., \& Wardono. (2019). Perlunya Kemampuan Literasi Matematika Ditinjau Dari Gaya Kognitif dalam Pembelajaran Realistic Mathematics Education (RME). PRISMA, Prosiding Seminar Nasional Matematika, 2, 234-238.

Ihsan, M. (2019). Pengembangan Bahan Ajar Matematika Realistik berbasis Alquran Pokok Bahasan Pecahan. Suska Journal of Mathematics Education, 5(1), 39. https://doi.org/10.24014/sjme.v5i1.6824 Ja'far, M., Sunardi, \& Indah, A. (2014). Pengembangan Perangkat Pembelajaran Berbasis Karakter Konsisten dan Teliti Menggunakan Pendekatan Realistic Mathematics Education (RME) pada Bab Kesebangunan dan Kekongruenan Bangun Datar Kelas IX SMP. Jurnal Edukasi UNEJ, 1(3), 29-35.

Lisnani, L., \& Asmaruddin, S. N. (2018). Desain Buku Ajar Matematika Bilingual Materi Bangun Datar Menggunakan Pendekatan PMRI Berkonteks Kebudayaan Lokal. Mosharafa: Jurnal Pendidikan Matematika, 7(3), 345-356. https://doi.org/10.31980/mosharafa.v7i3.134

Mahmudah, K. S., \& Fathani, A. H. (2019). Pengembangan Bahan Ajar Matematika dengan Pendekatan Pendidikan Matematika Realistik Indonesia pada Materi Sistem Persamaan Linier Dua Variabel 
Development of Mathematics Teaching Materials with Indonesian Realistic Mathematics Education Approach on Linea. Jurnal Komunikasi Pendidikan, Vol.3 No.1, 2019, 3(1). http://journal.univetbantara.ac.id/index.php/komdik/article/view/230

Marlinda, I., \& Wijaya, A. (2018). Pengembangan perangkat pembelajaran dengan pendekatan pendidikan matematika realistik berorientasi pada minat dan prestasi. Pythagoras: Jurnal Pendidikan Matematika, 13(1), 76-87. https://doi.org/10.21831/pg.v13i1.21171

Maryamah, I., Anriani, N., \& Fathurrohman, M. (2019). Pengembangan Bahan Ajar Materi Pythagoras yang Berorientasi pada Kompetensi Abad 21 untuk Guru SMP. SJME (Supremum Journal of Mathematics Education), 3(1), 67-77. https://doi.org/10.31235/osf.io/9z27d

Masfingatin, T. (2014). Proses Berpikir Siswa Sekolah Menengah Pertama Dalam Menyelesaikan Masalah Bangun Ruang Sisi Datar Berdasarkan Teori Van Hiele. JIPM (Jurnal Ilmiah Pendidikan Matematika), 3(1). https://doi.org/10.25273/jipm.v3i1.496

Mayani, S., \& Rizki, S. (2016). Pengembangan Bahan Ajar Berbasis Pendidikan Matematika Realistik (PMR) Pada Materi Program Linear. Aksioma, 5(17 (59)), 25-39.

Pangestu, R., Netriwati, \& Putra, R. W. Y. (2019). PENGEMBANGAN BAHAN AJAR GAMIFIKASI BERBASIS CONTEXTUAL TEACHING LEARNING ( CTL ) PADA MATERI PELUANG menggambarkan suatu kurikulum sebagai kombinasi yang membentuk kerangka isi materi. Prima: Jurnal Pendidikan Matematika, 3(1), 45-56.

Rofiroh. (2019). Pengembangan Bahan Ajar Realistik Pada Pokok. 3(1), 1-8.

Sandri, M. (2018). Pengaruh Media Lagu Terhadap Hasil Belajar Matematika Pada Materi Sifat-Sifat Bangun Datar Siswa Kelas 5 SD Negeri 5 Kota Bengkulu. JNPM (Jurnal Nasional Pendidikan Matematika), 2(1), 1. https://doi.org/10.33603/jnpm.v2i1.698

Sholihah, S. Z., \& Afriansyah, E. A. (2018). Analisis Kesulitan Siswa dalam Proses Pemecahan Masalah Geometri Berdasarkan Tahapan Berpikir Van Hiele. Mosharafa: Jurnal Pendidikan Matematika, 6(2), 287-298. https://doi.org/10.31980/mosharafa.v6i2.317

Ulya, M. R., Isnarto, Rochmad, \& Wardono. (2019). Efektivitas Pembelajaran Flipped Classroom dengan Pendekatan Matematika Realistik Indonesia terhadap Kemampuan Representasi Ditinjau dari SelfEfficacy. Jurnal PRISMA, 2, 116-123. 